\title{
Oral Pregabalin vs Oral Hormone in An Exceedingly Attenuation of Hemodyanamic Response to Laryngoscopy Insertion, Extubation in Patients Undergoing Laparoscopic Cholecystectomy
}

\author{
Akhilesh Mishra', Neelam Gupta ${ }^{2}$ \\ ${ }^{1}$ Assistant Professor, Department of Anesthesiology, Saraswathi Institute of Medical Sciences, Anwarpur, Hapur, Uttar Pradesh, India. ${ }^{2}$ Associate \\ Professor, Department of Anesthesiology, Saraswathi Institute of Medical Sciences, Anwarpur, Hapur, Uttar Pradesh, India.
}

\section{Abstract}

Background: Premedication in the form of vasodilators, adreno receptor blockers, calcium channel blockers and opioids were used earlier to attenuate these responses, with variable results. This study will be conducted to evaluate \& compare efficacy of oral pregabalin \& oral melatonin in attenuation of haemodynamic responses during laryngoscopy, intubation \& extubation in laparoscopic cholecystectomy. Subjects and Methods: This is a Prospective randomized double blind comparative study done on 60 Patients undergoing laparoscopic cholecystectomy in Department of Anesthesiology, Saraswathi Institute of Medical Sciences, Anwarpur, Hapur, Uttar Pradesh, India. All patients were explained about the anaesthesia technique and written informed consent taken. Group P - (30 patients) oral pregabalin 150mg, $120 \mathrm{~min}$ before surgery and Group M- (30 patients) oral melatonin tablets $6 \mathrm{mg}$ (two tablets of $3 \mathrm{mg}$ ), 120 min before surgery. Pre-anaesthetic evaluation was done a day prior. Patients to be kept NPO 8 hours prior to surgery. Results: Our study showed that the mean age of patients was $36.50 \pm 12.01$ years in group $\mathrm{P}$ and $34.70 \pm 14.82$ years in group $\mathrm{M}$, but statistically non-significant $(\mathrm{P}=0.6073)$. The heart rate, SBP, DBP \& Mean arterial pressure was statistical non-significant. The complications occurred more in group $\mathrm{P}$ as compare to group M. The bradycardia, headache was more common complications in both groups. Conclusion: We concluded that both the drugs can be used as an effective premedicant to attenuate the sympathetic response to laryngoscopy and tracheal intubation without much side effects and the added advantage of intraoperative and postoperative analgesia.

Keywords: Morphine, Oral Pregabalin, Endotracheal Intubation, Pre-Anaesthetic Evaluation.

Corresponding Author: Dr. Neelam Gupta, Associate Professor, Department of Anesthesiology, Saraswathi Institute of Medical Sciences, Anwarpur, Hapur, Uttar Pradesh, India.

Received: January 2019

Accepted: February 2019

\section{Introduction}

Laryngoscopy and endotracheal intubation during general anesthesia are associated with various cardiovascular changes such as hypertension, tachycardia, dysrhythmias and increased circulating catecholamines. ${ }^{[1]}$ The effect although is transient, from 30 seconds after intubation to upto 10 minutes. ${ }^{[2]}$ It occurs because of adrenergic response which leads to stimulation of the cardio-accelerator fibres.

Endotracheal intubation is well tolerated by normotensive patients, but even transient stimulation has been associated with increased morbidity and mortality in patients with preeclampsia, recent myocardial infarction, hypertension, and cerebro-vascular pathology such as aneurysms, tumors, or raised intracranial pressure. ${ }^{[3,4]}$

Laparoscopy is a technique for visualization of the internal organs of abdomen or pelvis with an aid of camera using small incisions for ports which became very popular in early 1990s because less postoperative complications and pain were noted as compared to open cholecystectomy.
Pregabalin, a gabapentinoid compound appears to produce an inhibitory modulation of neuronal excitability particularly in neocortex, amygdala and hippocampus of CNS. ${ }^{[5,6]}$

Pineal hormone melatonin (N-acetyl-5-methoxytryp-tamine) is an endogenous sleep regulating hormone that can be used as premedication, regulation of circadian rhythms, as sedative, analgesic, anti-inflammatory, and antioxidant. ${ }^{[7]}$ Various studies have been performed to study efficacy of drugs on attenuating haemodynamic responses to laryngoscopy. By far no study has been done to compare oral pregabalin \& oral melatonin. This study will be conducted to evaluate \& compare efficacy of oral pregabalin \& oral melatonin in attenuation of haemodynamic responses during laryngoscopy, intubation \&extubation in laparoscopic cholecystectomy.

\section{Subjects and Methods}

This is a Prospective randomized double blind comparative study done on 60 Patients undergoing laparoscopic cholecystectomy in Department of Anesthesiology, 
Saraswathi Institute of Medical Sciences, Anwarpur, Hapur, Uttar Pradesh, India.

\section{Inclusion Criteria}

- Sixty ASA grade I and II patients ,

- Age between 18-65 years,

- Under going laparoscopic cholecystectomy

\section{Exclusion criteria}

- Patients having compromised renal, pulmonary and cardiac status (ASA grade III or above )

- Patients with anemia, blood coagulation disorders, diabetes

- Patients with anticipated difficult intubation (mallampati grade 3 and 4)

- More than one attempts at intubation

- Patients in whom duration of laryngoscopy exceeds more than 30 secs

- Haemodynamically unstable patients (HR >120/min , $\mathrm{HR}<50 / \mathrm{min}$, systolic BP > $140 \mathrm{mmHg}$, systolic $\mathrm{BP}<90$ $\mathrm{mmHg}$, diastolic BP $>100 \mathrm{mmHg}$, diastolic $\mathrm{BP}<50 \mathrm{mmHg}$ )

- Previous History of allergy or contraindication to anaesthetics or any drug used.

- Patients unwilling to give consent for proposed study

- Patient with any GI disturbance which hinders enteric absorption to oral medicine

- Patients on chronic neuroleptic medication and taking tricyclic antidepressants or serotonin and NE uptake inhibitor.

- Patients who took medications that would influence automomic or cardiovascular response to laryngoscopy and intubation.

- Patient weighing $>20 \%$ of ideal body weight, pregnant or breastfeeding females

\section{Method}

This study was done at Department of Anesthesiology, Saraswathi Institute of Medical Sciences, Anwarpur, Hapur, Uttar Pradesh, India. Permission from hospital ethical committee and written informed consent were obtained.

Patients were randomly divided into two groups of 30 each with the help of a chit box method. All patients were explained about the anaesthesia technique and written informed consent taken.

Group P: (30 patients) oral pregabalin 150mg, $120 \mathrm{~min}$ before surgery.

Group M: (30 patients) oral melatonin tablets $6 \mathrm{mg}$ (two tablets of $3 \mathrm{mg}$ ), $120 \mathrm{~min}$ before surgery.

Pre-anaesthetic evaluation was done a day prior. Patients to be kept NPO 8 hours prior to surgery.

On the day of surgery, patient received in OT, confirmation of patient's identity, fasting status, PAC and consent was done.

In the operating room standard 5 leads ECG, non-invasive blood pressure and pulse oximetry were attached and base line parameters were noted. Venous access was secured using an $18 \mathrm{G}$ cannula on the dorsum of the non-dominant hand. Injection midazolam $1 \mathrm{mg}$ and fentanyl $1 \mu \mathrm{g} / \mathrm{kg}$ were given. Pre-oxygenation was done for 3 minutes, then induction with i.v propofol $2 \mathrm{mg} / \mathrm{kg}$. Succinylcholine were used intravenously $2 \mathrm{mg} / \mathrm{kg}$ to facilitate endotracheal intubation with proper sized well- lubricated cuffed endotracheal tube. Laryngoscopy and tracheal intubation was done with appropriate sized, cuffed endotracheal tube. Maintenance of anaesthesia with inhalation of isoflurane 1 minimum alveolar concentration; nitrous oxide: oxygen 40:60. Muscle relaxation were attained with Vecuronium bromide in the dose of $0.06-0.08 \mathrm{mg} / \mathrm{kg}$ intravenously as loading dose and one- fourth of the initial dose as maintenance doses.

After completion of the surgery, neostigmine $50 \mu \mathrm{g} / \mathrm{kg}$ and injection glycopyrrolate $10 \mu \mathrm{g} / \mathrm{kg}$ were administered intravenously to reverse the residual neuromuscular blockade.

\section{Statistical Analysis}

Data are expressed as mean, intra group difference was evaluated by two way analysis of variance (ANOVA), and intergroup using t-test. $\mathrm{P}$ values of $<0.05$ were considered significant.

\section{Results}

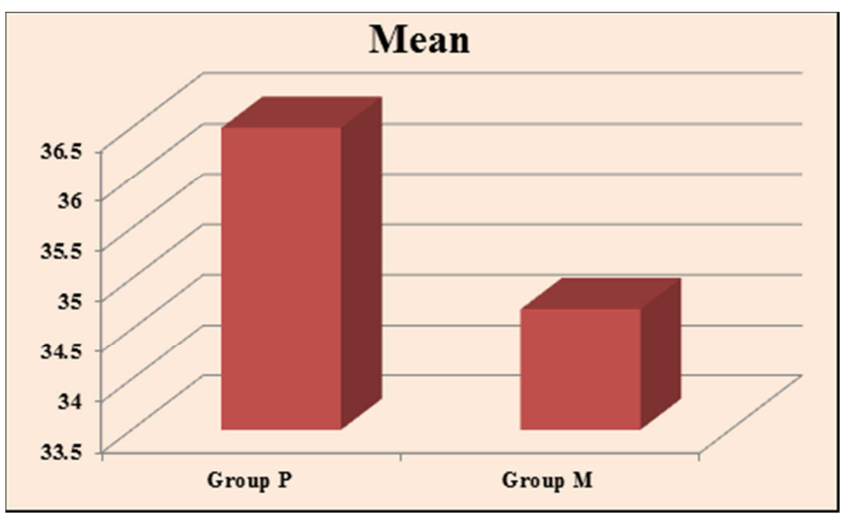

Figure 1: Distribution of mean age in between groups

Table 1: Comparison of heart rate in different time interval in between groups

\begin{tabular}{|c|c|c|c|c|c|c|}
\hline \multirow[t]{2}{*}{ Heart Rate } & \multicolumn{2}{|c|}{$\begin{array}{l}\text { Melatonin } \\
\text { group }\end{array}$} & \multicolumn{2}{|c|}{$\begin{array}{l}\text { Pregabalin } \\
\text { group }\end{array}$} & \multirow[t]{2}{*}{ t-value } & \multirow[t]{2}{*}{$\begin{array}{l}\text { P- } \\
\text { value }\end{array}$} \\
\hline & $\begin{array}{l}\text { Mea } \\
\text { n }\end{array}$ & SD & $\begin{array}{l}\text { Mea } \\
\text { n }\end{array}$ & SD & & \\
\hline Baseline & 85.43 & $\begin{array}{l}8.08 \\
0\end{array}$ & 87.17 & $\begin{array}{l}8.91 \\
4\end{array}$ & 0.7891 & $\begin{array}{l}0.433 \\
3\end{array}$ \\
\hline $\begin{array}{l}\text { During } \\
\text { laryngoscopy } \quad \& \\
\text { Intubation }\end{array}$ & 92.17 & $\begin{array}{l}9.35 \\
2\end{array}$ & $\begin{array}{l}95.33 \\
\end{array}$ & $\begin{array}{l}8.01 \\
4\end{array}$ & 1.408 & $\begin{array}{l}0.164 \\
4\end{array}$ \\
\hline $5 \mathrm{~min}$. & 82.37 & $\begin{array}{l}9.00 \\
0\end{array}$ & 83.83 & $\begin{array}{l}11.0 \\
8\end{array}$ & 0.5627 & $\begin{array}{l}0.575 \\
8\end{array}$ \\
\hline $\begin{array}{l}\text { Before } \\
\text { pneumoperitoneu } \\
\text { m }\end{array}$ & 79.93 & $\begin{array}{l}8.58 \\
2\end{array}$ & 82.83 & $\begin{array}{l}9.45 \\
4\end{array}$ & 1.244 & $\begin{array}{l}0.218 \\
5\end{array}$ \\
\hline $\begin{array}{l}30 \text { min. after } \\
\text { pneumoperitoneu } \\
m\end{array}$ & 83.77 & $\begin{array}{l}5.77 \\
6\end{array}$ & 83.70 & $\begin{array}{l}9.76 \\
3\end{array}$ & $\begin{array}{l}0.0321 \\
9\end{array}$ & $\begin{array}{l}0.974 \\
4\end{array}$ \\
\hline After $\mathrm{CO} 2$ release & 83.37 & $\begin{array}{l}7.48 \\
6 \\
\end{array}$ & 83.47 & $\begin{array}{l}9.64 \\
1 \\
\end{array}$ & 0.4487 & $\begin{array}{l}0.964 \\
4 \\
\end{array}$ \\
\hline After extubation & 88.17 & $\begin{array}{l}6.48 \\
7\end{array}$ & 89.60 & $\begin{array}{l}5.58 \\
7\end{array}$ & 0.9170 & $\begin{array}{l}0.362 \\
9\end{array}$ \\
\hline
\end{tabular}

Our study showed that the mean age of patients was $36.50 \pm 12.01$ years in group $\mathrm{P}$ and $34.70 \pm 14.82$ years in group $\mathrm{M}$, but statistically non-significant $(\mathrm{P}=0.6073)$ [Figure 
1]. The heart rate in group $M$ was slightly lower as compare to group $\mathrm{P}$, but statistically non-significant in between groups [Table 1].

The mean value of SPO2 was slightly higher in group $\mathrm{M}$ as compare to group $\mathrm{P}$. The difference was statistical significant in various time interval in our study [Table 2]. The complications occurred more in group $\mathrm{P}$ as compare to group M. The bradycardia, headache was more common complications in both groups.

Table 2: Comparison of SPO2 in different time interval in between groups

\begin{tabular}{|c|c|c|c|c|c|c|}
\hline \multirow[t]{2}{*}{ SPO2 } & \multicolumn{2}{|c|}{$\begin{array}{l}\text { Melatonin } \\
\text { group }\end{array}$} & \multicolumn{2}{|c|}{$\begin{array}{l}\text { Pregabalin } \\
\text { group }\end{array}$} & \multirow{2}{*}{$\begin{array}{l}\text { t- } \\
\text { valu } \\
\text { e }\end{array}$} & \multirow[t]{2}{*}{ P-value } \\
\hline & $\begin{array}{l}\text { Mea } \\
\text { n }\end{array}$ & SD & $\begin{array}{l}\text { Mea } \\
\text { n }\end{array}$ & SD & & \\
\hline Baseline & 99.43 & $\begin{array}{l}0.504 \\
0\end{array}$ & 99.70 & $\begin{array}{l}0.466 \\
1\end{array}$ & $\begin{array}{l}2.12 \\
8\end{array}$ & $0.0376 *$ \\
\hline $\begin{array}{l}\text { During } \\
\text { laryngoscopy \& } \\
\text { Intubation }\end{array}$ & 99.93 & $\begin{array}{l}0.253 \\
7\end{array}$ & 99.67 & $\begin{array}{l}0.479 \\
5\end{array}$ & $\begin{array}{l}2.69 \\
3\end{array}$ & $0.0093^{* * *}$ \\
\hline $5 \mathrm{~min}$. & 99.97 & $\begin{array}{l}0.182 \\
6\end{array}$ & 99.70 & $\begin{array}{l}0.466 \\
1\end{array}$ & $\begin{array}{l}2.91 \\
8\end{array}$ & $0.0050^{* * *}$ \\
\hline $\begin{array}{l}\text { Before } \\
\text { pneumoperitoneu } \\
\mathrm{m}\end{array}$ & 99.97 & $\begin{array}{l}0.182 \\
6\end{array}$ & 99.60 & $\begin{array}{l}0.498 \\
3\end{array}$ & $\begin{array}{l}3.78 \\
5\end{array}$ & $\begin{array}{l}0.0004 * * \\
*\end{array}$ \\
\hline $\begin{array}{l}30 \text { min. after } \\
\text { pneumoperitoneu } \\
\mathrm{m}\end{array}$ & 99.93 & $\begin{array}{l}0.365 \\
1\end{array}$ & 99.80 & $\begin{array}{l}0.406 \\
8\end{array}$ & $\begin{array}{l}1.33 \\
6\end{array}$ & 0.1868 \\
\hline $\begin{array}{ll}\begin{array}{l}\text { After } \\
\text { release }\end{array} & \mathrm{CO} 2 \\
\end{array}$ & 99.93 & $\begin{array}{l}0.365 \\
1 \\
\end{array}$ & 99.73 & $\begin{array}{l}0.449 \\
8 \\
\end{array}$ & $\begin{array}{l}1.89 \\
1 \\
\end{array}$ & 0.0636 \\
\hline After extubation & 99.93 & $\begin{array}{l}0.253 \\
7\end{array}$ & 99.73 & $\begin{array}{l}0.449 \\
8\end{array}$ & $\begin{array}{l}2.12 \\
1\end{array}$ & $0.0382 *$ \\
\hline
\end{tabular}

Table 3: Complications

\begin{tabular}{|l|l|l|}
\hline Complications & Melatonin group & Pregabalin group \\
\hline Bradycardia & 1 & 2 \\
\hline Headache & 0 & 0 \\
\hline nausea/vomiting & 1 & 2 \\
\hline Restlessness & 0 & 1 \\
\hline Arrhythmia & 0 & 0 \\
\hline Hypotension & 1 & 0 \\
\hline
\end{tabular}

\section{Discussion}

Airway management is one of the core skills of the anaesthetist, either via facemask ventilation, insertion of a laryngeal mask airway, endotracheal intubation by direct or indirect (video-assisted) laryngoscopy or by use of a fibrescope. Pain relieving agents are usually administered with the concept of balanced analgesia, which involves a combination of analgesics with either synergistic or additive effects.

Various study done by Kumkum Gupta et al (2011), ${ }^{[8]}$ aged 35 to 52 years, Shirin Parveen et al (2016), ${ }^{[9]}$ included aged between 20-60 years of both sexes, Bhawna Rastogi et al $(2012),{ }^{[10]}$ aged $24-56$ years. Another study done by Nadia M Bahgat et al (2016), ${ }^{[1]}$ aged $18-60$ years. No significant difference was found in age, sex in our study.

Bhawna Rastogi et al (2012), ${ }^{[10]}$ found no significant decrease in heart rate was observed in different doses of pregabalin. Mohamed, Hosam M. et al (2013), ${ }^{[12]}$ found no significant difference in heart rate between the different doses of melatonin. Another study done by Dhananjaya
Doddaiah et al (2017), ${ }^{[13]}$ found that the increase in HR response to laryngoscopy and intubation was minimized by both gabapentin and pregabalin when compared with the control group $(\mathrm{P}<0.05)$ at baseline and $1 \mathrm{~min}$; however, there was no statistically significant difference between the two study groups $(\mathrm{P}>0.05)$.

The complications occurred more in group $\mathrm{P}$ as compare to group M. Shirin Parveen et al (2016), ${ }^{[9]}$ concluded that both the drugs can be used as an effective premedicant to attenuate the sympathetic response to laryngoscopy and tracheal intubation without much side effects and the added advantage of intraoperative and postoperative analgesia.

\section{Conclusion}

We concluded that both the drugs can be used as an effective premedicant to attenuate the sympathetic response to laryngoscopy and tracheal intubation without much side effects and the added advantage of intraoperative and postoperative analgesia.

\section{References}

1. Russell WJ, Morris RG, Frewin DB, Drew SE. Changes in plasma catecholamine concentrations during endotracheal intubation. $\mathrm{Br} \mathrm{J}$ Anaesth. 1981;53(8): 837-39.

2. Gupta A, Wakhloo R, Gupta V, Mehta A, Kapoor BB. Comparison of Esmolol and Lignocaine for Atttenuation of Cardiovascular Stress response to Laryngoscopy and Endotracheal Intubation. 2009;11:0-3.

3. Channaiah V.B., Chary K., Vlk J.L., Wang Y. And Chnadra S.B.C.: Low dose fentanyl: Hemodynamic response to endotracheal intubation in normotensive patients. Arch. Med. Sci., 4 (3): 293-9, 2008.

4. Malde A.D. and Sarode V.: Attenuation of the hemodynamic response to endotracheal intubation: Fentanyl versus lignocaine. Br. J. Anaesth., 59: 295-9, 1987

5. Taylor CP, Angelotti T, Fauman E. Pharmacology and mechanism of action of pregabalin: the calcium channel alpha2-delta (alpha2-delta) subunit as a target for antiepileptic drug discovery. Epilepsy Res. 2007;73(2):137-50

6. Ben-Menachem E. Pregabalin pharmacology and its relevance to clinical practice. Epilepsia. 2004;45:13-18.

7. Arangino S., Cagnacci A., Angiolucci M. Andvacca A.M. Effects of melatonin on vascular reactivity, catecholamine levels, and blood pressure in healthy men. Am. J. Cardiol., 83: 1417-19, 1999.

8. Gupta K, Sharma D, Gupta PK. Oral premedication with pregabalin or clonidine for haemodynamic stability during laryngoscopy and laparoscopic cholecystectomy: A comparative evaluation. Saudi Journal of Anaesthesia. 2011;5(2):179-84.

9. Shirin Parveen, Devendra Singh Negi, Rajesh Kumar, and Mohd Chand Bagwan. Oral Clonidine vs Oral Pregabalin Premedication to Attenuate Pressor Response to Direct Laryngoscopy in Patients Undergoing Laparoscopic Cholecystectomy: A Randomized Double Blind Study. J Clin Diagn Res. 2016 Sep; 10(9): UC21-UC25.

10. Rastogi B, Gupta K, Gupta PK, Agarwal S, Jain M, Chauhan H. Oral pregabalin premedication for attenuation of haemodynamic pressor response of airway instrumentation during general anaesthesia: A dose response study. Indian J Anaesth 2012:56:49-54

11. Bahgat NM, Sadik SA, Mahdy WR, El-Sharkawy OA, Metwally AA, El-Shafey MK. The effects of using pregabalin versus clonidine premedication in laparoscopic cholecystectomy. Menoufia Med J 2016;29:530-8

12. Mohamed AA, Atef HM, El Kassaby AM, Ismail SA, Helmy AM. Effects of melatonin premedication premedication on the haemodynamic responses and perfusion index during laryngoscopy and endotracheal intubation.Med J Cairo Uni. 2013;81:859-67.

13. Doddaiah DB, Singh NR, Fatima N, Singh SS, Singh HK, Singh KS. A comparative study of oral pregabalin and oral gabapentin in the attenuation of hemodynamic response to laryngoscopy and intubation. $\mathbf{J}$ Med Soc 2017;31:14-8. 
Copyright: () the author(s), publisher. Academia Anesthesiologica International is an Official Publication of "Society for Health Care \& Research Development". It is an open-access article distributed under the terms of the Creative Commons Attribution Non-Commercial License, which permits unrestricted non-commercial use, distribution, and reproduction in any medium, provided the original work is properly cited.

How to cite this article: Mishra A, Gupta N. Oral Pregabalin vs Oral Hormone in An Exceedingly Attenuation of Hemodyanamic Response to Laryngoscopy Insertion, Extubation in Patients Undergoing Laparoscopic Cholecystectomy. Acad. Anesthesiol. Int. 2019;4(1):93-96.

DOI: dx.doi.org/10.21276/aan.2019.4.1.21

Source of Support: Nil, Conflict of Interest: None declared. 